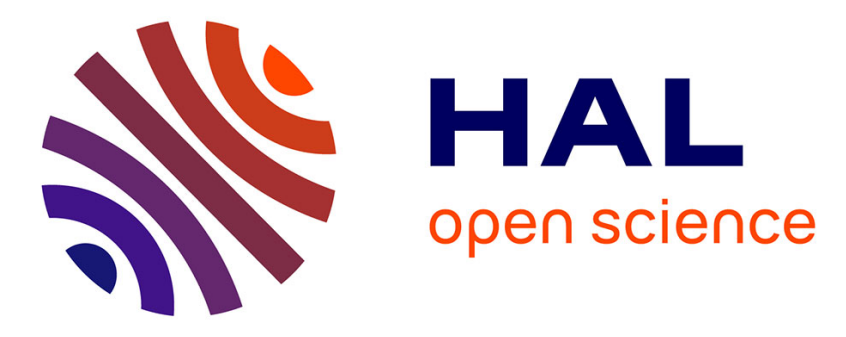

\title{
Sorption of nalidixic acid onto micrometric and nanometric magnetites: experimental study and modeling
}

Muhammad Usman, Sébastien Martin, Nicolas Cimetiere, Sylvain Giraudet, Vincent Chatain, Khalil Hanna

\section{To cite this version:}

Muhammad Usman, Sébastien Martin, Nicolas Cimetiere, Sylvain Giraudet, Vincent Chatain, et al.. Sorption of nalidixic acid onto micrometric and nanometric magnetites: experimental study and modeling. Applied Surface Science, 2014, 299, pp.136-145. 10.1016/j.apsusc.2014.01.197 . hal00953734

\section{HAL Id: hal-00953734 \\ https://hal.science/hal-00953734}

Submitted on 28 Feb 2014

HAL is a multi-disciplinary open access archive for the deposit and dissemination of scientific research documents, whether they are published or not. The documents may come from teaching and research institutions in France or abroad, or from public or private research centers.
L'archive ouverte pluridisciplinaire HAL, est destinée au dépôt et à la diffusion de documents scientifiques de niveau recherche, publiés ou non, émanant des établissements d'enseignement et de recherche français ou étrangers, des laboratoires publics ou privés. 
Sorption of nalidixic acid onto micrometric and nanometric magnetites: experimental study and modeling

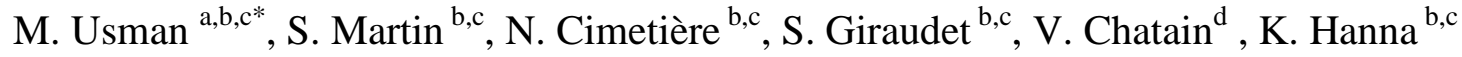

${ }^{a}$ Institute of Soil and Environmental Sciences, University of Agriculture, Faisalabad, 38040, Pakistan.

${ }^{\mathrm{b}}$ Ecole Nationale Supérieure de Chimie de Rennes, CNRS, UMR 6226, 11 Allée de Beaulieu, CS 50837, 35708 Rennes Cedex 7, France.

${ }^{c}$ Université Européenne de Bretagne, France.

${ }^{\mathrm{d}}$ Université de Lyon, INSA-Lyon, Laboratoire de Génie Civil et d'Ingénierie Environnementale LGCIE, 20 avenue Albert Einstein, 69621 Villeurbanne, France.
}

* Corresponding author:

Institute of Soil and Environmental Sciences, University of Agriculture, Faisalabad-38040, Pakistan

Tel: +92419201220

Fax: +92419200764

Email: muhammad.usman@uaf.edu.pk

Alternative Email: musmanch@yahoo.com 


\begin{abstract}
The sorption of nalidixic acid (NA) was studied onto three kinds of magnetite characterized by different particle sizes (from micrometric to nanometric) and surface properties. Experiments were performed under static batch and dynamic flow conditions. Obtained results indicate that kinetics and extent of sorption was strongly affected by the particle size of tested magnetites. Ionic strength effect was less significant suggesting that aggregation state of the magnetite particles did not affect the sorption. During kinetic sorption experiments, apparent rate constant normalized to solid mass was faster for nanosized magnetite while an opposite trend was observed for the surface area-normalized rate constants. Infrared data suggested the possibility of similar surface interactions on both microsized and nanosized magnetites. Transport of NA in magnetite-packed column was found associated to the instantaneous sorption without any significant effect of kinetic limitation. Breakthrough curves (BC) and sorption extent in columns were calculated by using Thomas, Yan and YoonNelson models. Sorption capacities predicted by Thomas or Yan model were in good agreement with that determined by integrating total area above BC. However, Thomas model failed particularly to predict an accurate concentration at lower and higher time points of the BC. These findings have strong implications in relation to the transport and removal of environmental pollutants in natural and engineered systems.
\end{abstract}

Keywords: magnetite; nalidixic acid; sorption; transport; column; modeling. 


\section{Introduction}

In environment, iron minerals are commonly found as ferric oxides including goethite, ferrihydrite, hematite and lepidocrocite [1] . Another form of iron minerals is the mixed $\mathrm{Fe}^{\mathrm{II}}-$ $\mathrm{Fe}^{\mathrm{III}}$ oxides including magnetite $\left(\mathrm{Fe}_{3} \mathrm{O}_{4}\right)$ and green rust. Magnetite $\left(\mathrm{Fe}^{\mathrm{II}} \mathrm{Fe}^{\mathrm{III}}{ }_{2} \mathrm{O}_{4}\right)$ is very efficient in environmental remediation owing to its stability and presence of structural $\mathrm{Fe}^{\mathrm{II}}[2-$ 5]. Magnetite is a ubiquitous iron oxide in soils and sediments. Existence of magnetite was reported in weathered clays, soils and in recent deposits of marine and freshwater sediments $[6,7]$. Recently, magnetite was identified as the main constituent of iron corrosion scale in drinking water distribution systems [8]. Top layers of corrosion scale were dominated by magnetite [8, 9].

Magnetite can also be formed in laboratory by various abiotic and biotic procedures. Formation of biogenic magnetite was reported as a result of microbial reduction of ferric oxyhydroxides [10]. Abiotic procedures to form magnetite include co-precipitation of $\mathrm{Fe}^{\mathrm{II}}$ and $\mathrm{Fe}^{\mathrm{III}}$ salts in aqueous solutions or partial oxidation of hydroxylated $\mathrm{Fe}^{\mathrm{II}}$ solution [11]. Magnetite can also be formed by reacting aqueous $\mathrm{Fe}^{\mathrm{II}}$ with ferric oxides inducing their structural modifications and bulk phase transformations [12, 13]. The morphology, crystallography and specific surface area of natural or synthetic magnetite can vary widely. Magnetite exists as micrometric and nanometric particles in many natural and engineered environments. Because of the larger specific surface area of nanosized particles, their surface reactivity is exalted and they play preeminent role in sorption of environmental pollutants.

Many studies have been carried out to evaluate the magnetite adsorption capacity for different pollutants including heavy metals, oxyanions and radionuclides [14-18]. However, less information is available about the mechanism and extent of sorption of emerging organic contaminants especially pharmaceutical compounds. Therefore, it is important to consider the potential mobilization risks of water pollution associated with these contaminants, and to investigate their interaction with magnetite.

Although large variability of magnetite is found in natural as well as engineered systems, sorption onto different magnetites has never been reported.. The impact of particle size and morphology on magnetite sorption capability merits, therefore, to be investigated form both environmental and engineering aspects. Moreover, the interactions of environmental pollutants with magnetite were mainly investigated under batch conditions [16-18]; however transport of such contaminants in magnetite-packed column has scarcely been investigated under flow-through conditions. Contrary to batch tests, column experiments allow monitoring 
the effect of non-equilibrium sorption onto the transport of pollutants. Effect of hydrodynamic parameters (e.g. dispersion) on the solute breakthrough can also be evaluated in continuous flow through conditions. Estimation of field parameters could be more accurate in column tests which provide a suitable soil-aqueous phase ratio. Moreover, sorbate species can be flushed out of system in continuous flow conditions, ultimately affecting the kinetics and extent of reaction.

Present study was conducted to investigate sorption of NA (used as a model pharmaceutical pollutant), onto three kinds of magnetite. Sorption was evaluated vs. time, $\mathrm{pH}$ and ionic strength in batch experiments. Sorption isotherms were also recorded over a wide range of NA concentration. Fourier transform infrared in transmission mode (FTIR) was also used to recognize the main surface complexes structures. Flow through experiments were also conducted at two influent concentrations (50 and $200 \mu \mathrm{M}$ of NA) and at a relatively lower flow rate (i.e. $0.2 \mathrm{~mL} / \mathrm{min}$ ). Three different models (Thomas, Yan and Yoon-Nelson) were used to estimate the amount of NA sorbed in the column. Application of these semi-empirical models to determine the sorbed quantity of emerging organic pollutants in iron-mineral coated sand columns remains sparse.

\section{Experimental Procedures}

\subsection{Chemical Reagents}

Nalidixic acid (NA), sodium phosphate $\left(\mathrm{Na}_{3} \mathrm{PO}_{4} \cdot 12 \mathrm{H}_{2} \mathrm{O}\right)$, ferrous chloride tetrahydrate $\left(\mathrm{FeCl}_{2} \cdot 4 \mathrm{H}_{2} \mathrm{O}\right)$, ferrous sulfate heptahydrate $\left(\mathrm{FeSO}_{4} \cdot 7 \mathrm{H}_{2} \mathrm{O}\right)$ and ferric chloride hexahydrate $\left(\mathrm{FeCl}_{3} .6 \mathrm{H}_{2} \mathrm{O}\right)$ were provided by Sigma Aldrich. Fontainebleau sand (France) was purchased from Prolabo (grain size range $=100-250 \mu \mathrm{m}$ ).

\subsection{Formation and characterization of magnetite (M) and magnetite coated sand (MCS)}

Experiments were conducted with three different kinds of magnetite $\left(\mathrm{Fe}^{\mathrm{II}} \mathrm{Fe}^{\mathrm{III}} \mathrm{O}_{4}\right)$. Among them, two (M1 and M2) were prepared in lab, while third one (M3) was purchased from Prolabo. M1 and M2 were formed by mineralogical transformations of 2-line ferrihydrite and lepidocrocite $(\gamma-\mathrm{FeOOH})$, respectively as previously reported [12]. Prior to reactivity tests, all magnetites were analyzed by X-ray powder diffraction (XRD), Transmission electron microscopy (TEM) and Fourier transform infrared spectrometer (FTIR) as described previously [2]. 
Magnetite coated sand (MCS) was prepared as described by Scheiddeger et al. [19] and as explained previously $[20,21]$ by using $1 \mathrm{~g}$ of each magnetite per $100 \mathrm{~g}$ of sand $(1 \% \mathrm{w} / \mathrm{w})$. Mineral characterization of sand was found to be exclusively quartz by XRD.

\subsection{Sorption experiments}

\subsubsection{Batch tests}

Kinetic sorption was evaluated at $200 \mu \mathrm{M}$ of NA concentration, at a fixed $\mathrm{pH}$ (6.5) and ionic strength $\left(\mathrm{NaCl} 10^{-2} \mathrm{M}\right)$ and at $20{ }^{\circ} \mathrm{C}$ in the absence of light. The sorption isotherms were recorded at $\mathrm{pH}$ of 6.5 and wide range of NA concentration $(2-200 \mu \mathrm{M})$. The sorption edge experiments were performed at a fixed NA concentration $(50 \mu \mathrm{M})$ and ionic strength $(\mathrm{NaCl}$ $\left.10^{-2} \mathrm{M}\right)$. Suspensions were centrifuged, filtered and the filtrate samples were subjected to analyses by UV-visible spectroscopy and depletion method was used to calculate the sorbed concentrations. Negligible quantity of dissolved Fe was detected by colorimetric method. The sorption tests are detailed previously [22, 23].

To investigate the effects of ionic strength and that of phosphate, batch sorption experiments were carried out at various molar concentrations $\left(10^{-4}-10^{-1} \mathrm{M}\right)$ of $\mathrm{NaCl}$, and of phosphate $\left(10^{-5}-10^{-2} \mathrm{M}\right)$. In order to determine the mass balance, solid phase extraction was conducted using acetonitrile as an organic solvent.

The sorption tests were performed in triplicate and their standard deviation was found to be less than $5 \%$.

\subsubsection{Column experiments}

Dry MCS (50 g) was packed into glass columns having internal diameter of $2.6 \mathrm{~cm}$ providing bed length of $6.3 \mathrm{~cm}$ and bulk density of $1.49 \mathrm{~g} / \mathrm{cm}^{3}$. Each column contained $0.5 \mathrm{~g}$ of the reactive material, i.e. magnetite.

The column was then saturated with a $10^{-2} \mathrm{~mol} \mathrm{~L}^{-1} \mathrm{NaCl}$ solution at a fixed flow rate $(0.2$ $\mathrm{mL} / \mathrm{min} ; q=0.037 \mathrm{~cm} / \mathrm{min})$. The hydrodynamic parameters were determined by a bromide tracer experiment (using a $10^{-2} \mathrm{~mol} \mathrm{~L}^{-1} \mathrm{KBr}$ solution) and using classical Convection Dispersion Equation (CDE) as explained previously [22, 24, 25]:

$$
\frac{\partial C}{\partial t}=D \frac{\partial^{2} C}{\partial x^{2}}-v \frac{\partial C}{\partial x}
$$

where $c$ is the water solute concentration $\left(\mathrm{M} / \mathrm{L}^{3}\right), t$ denotes time $(\mathrm{T}), x$ is the spatial coordinate (L), $D$ represents the dispersion coefficient $\left(\mathrm{L}^{2} / \mathrm{T}\right), q$ is the flow velocity $\left(\mathrm{L}^{-\mathrm{T}^{-1}}\right), \theta$ is the 
volumetric water content $\left(\mathrm{L}^{3} / \mathrm{L}^{3}\right)$, and $v$ is the darcian velocity $=\mathrm{q} / \theta\left(\mathrm{L} \cdot \mathrm{T}^{-1}\right)$. The breakthrough curve of bromide exhibited a slight asymmetrical shape with little tailing (data is not presented). The bromide concentration was analyzed using $\mathrm{CDE}$ to estimate the values of $\theta$ and D which represents flow homogeneity, as explained previously [23, 25, 26]. NA solution $(200 \mu \mathrm{M}, \mathrm{pH}=6)$ was then injected in a continuous mode into the column at the same constant flow rate $\left(0.2 \mathrm{~mL} \mathrm{~min}^{-1}\right)$, under $\mathrm{O}_{2}$-free controlled atmosphere. 


\section{Results and discussion}

\subsection{Characterization of tested magnetites}

Three kinds of magnetite were analyzed by XRD and their diffractograms are shown in Figure 1a. Five different peaks are represented in XRD diffractograms at $2 \theta=21.2^{\circ}, 35^{\circ}, 41.2^{\circ}$, $50.4^{\circ}$ and $62.8^{\circ}$ which could be assigned to magnetite in all diffractograms. These main peaks have $\mathrm{d}$-space values of $2.53,2.96,2.09,4.85$ and $1.71 \AA$ which may correspond to the more intense lines 311,220,400, 111 and 422, respectively of magnetite.

Morphology of three kinds of magnetite is shown by TEM images (Fig. 1b). M1 is characterized by smaller particles with non-uniform size or shape. But, shape of M2 particles is between hexagonal to octahedral while M3 exhibits non-uniform size and shape. Particle size of tested magnetites was in following order; M1 $<$ M2 $<$ M3 while a reverse order was found for BET surface area (M1 > M2 > M3) (Table 1). If particles are considered to be spherical, the radius of these particles $\left(\rho=5.15 \times 10^{6} \mathrm{~g} \mathrm{~m}^{-3}\right)$ could be correlated to the surface area as $\mathrm{SSA}_{\mathrm{Geo}}=6 /(\rho \mathrm{d})$. A good agreement between SSA determined by BET and SSA $\mathrm{Seo}_{\mathrm{G}}$ was observed except for M1. The disagreement observed for M1 might be caused by the existence of particles with wide range of particle size, and/or some impurities like ferrihydrite remaining during synthesis. Point of zero charge (PZC) determined by potentiometric titration was similar to that described in literature (Table 1) [5].

Sun and co-workers [27] proposed an approximation to determine the theoretical maximum surface proton binding site concentration $\left(P_{S}\right)\left(\mathrm{mol} \mathrm{L}^{-1}\right)$ using the following expression:

$P_{s}=\frac{S \cdot A \cdot Z \cdot N_{S}}{N_{A} \cdot v^{2 / 3}}$

Where $S$ represents the concentration of solid $(0.5 \mathrm{~g} / \mathrm{L}), A$ is the specific surface area, $Z$ represents the number of formula units/unit cell ( 8 for magnetite), $N s$ denotes average number of protons per unit surface (it is assumed that proton is bounded at three hydrated surface iron sites), $N_{A}$ is Avogadro's number, and $v$ is cell volume of magnetite $\left(5.91 \times 10^{-28} \mathrm{~cm}^{3}\right)$. These estimated values (Table 1) were, however, considerably higher than those of the concentration of surface proton binding sites obtained by potentiometric titrations. These observations are similar to those of Sun and co-workers [27], which suggest that only a small part of ironsurface site seems to be involved in proton binding. 


\subsection{Batch sorption results}

Kinetic results: The sorption kinetics of NA showed that solute uptake reached equilibrium values at about $500 \mathrm{~min}$ for all solids (Fig. 2a). Various models namely pseudo-first-order, pseudo-second-order and intraparticle diffusion models were employed in order to evaluate the kinetic sorption mechanism. First-order and intraparticle diffusion models result in poor regression $\left(r^{2}\right)$ of coefficient (data not shown). However, the pseudo-second-order rate expression appears to provide the best fitting kinetic model for the experimental data. The equation of pseudo-second-order can be expressed as:

$$
\frac{d q}{d t}=k_{2}\left(q_{e}-q_{t}\right)^{2}
$$

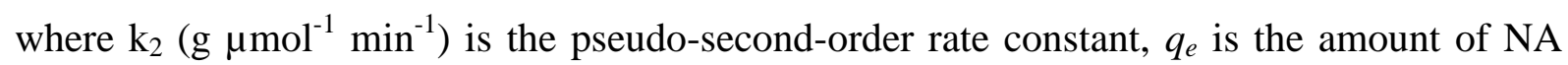
adsorbed at equilibrium $\left(\mu \mathrm{mol} \mathrm{g}{ }^{-1}\right.$ ) and $q_{t}$ is the amount of the adsorption ( $\mu \mathrm{mol} \mathrm{g}{ }^{-1}$ ) at any time $t$. Integration and rearrangement of Equation (4) gives:

$$
\frac{t}{q_{t}}=\frac{1}{k_{2} q_{e}{ }^{2}}+\frac{1}{q_{e}} t
$$

Pseudo-second-order rate constants $\left(\mathrm{k}_{2}\right.$ and $\left.\mathrm{q}_{\mathrm{e}}\right)$ were calculated from the slope and intercept of the plots of $\mathrm{t} / \mathrm{q}_{\mathrm{t}} v s$. $\mathrm{t}$. The value of the constant $k_{2}$ determined by regression analysis are reported in Table 2. Kinetics of NA sorption followed the pseudo-second-order model, which suggests that chemisorption could be the adsorption rate-limiting step and NA adsorption occurs probably via surface complexation reactions at specific sorption sites.

It is generally known, the longer the compound is adsorbed on the surface, the stronger is its binding [28]. Thus, in present batch tests, M1 showed highest sorption extent and lowest sorption rate constant normalized per mass unit. However, this trend is modified and the constant rates values are closer to each other, when normalized to surface area.

Mass transfer rates were estimated to evaluate the potential role of diffusion, either stationary layer diffusion from the solution to the surface, or inter-particle pore diffusion to reach the sorption sites within the magnetite aggregates. The rate of diffusion $\alpha$ can be written as:

$\alpha=\frac{D}{L^{2}}$

where $D$ is the diffusion coefficient $\left(\mathrm{cm}^{2} / \mathrm{s}\right)$, and $L$ is the thickness of the stagnant liquid film (cm).

Diffusion coefficient of solutes is usually $\sim 10^{-9} \mathrm{~m}^{2} / \mathrm{s}$ in liquids and thickness of stagnant layer of the liquid film can be estimated by film theory as $\sim 10^{-6} \mathrm{~m}$ [29]. Therefore, mass transfer 
rate of solute through the liquid film by diffusion (external mass transfer resistance) and the rate of diffusion are estimated to $10^{-3} \mathrm{~m} / \mathrm{s}$ and to $10^{3} \mathrm{~s}^{-1}$ respectively. Length of diffusion in nano-particle aggregates must be considered to assess the pore diffusion rate (resistance of internal mass transfer). Average size of aggregate could be roughly estimated by considering it as the average pore length for the particles of tested magnetite, and it lies at $\sim 10^{-6} \mathrm{~m}$. The effective diffusivity of solutes in the pores is generally $\sim 10^{-10} \mathrm{~m}^{2} / \mathrm{s}$ [30]. Therefore, the internal mass transfer and the internal diffusion rate are estimated at $10^{-4} \mathrm{~m} / \mathrm{s}$ and $10^{2} \mathrm{~s}^{-1}$, respectively.

Rate of NA sorption onto magnetite was assessed from the kinetic data and maximum sorbed amount $\left(\mathrm{k}_{2}\right.$.qe $\left.\left(\mathrm{s}^{-1}\right)\right)$ varied between $5.110^{-4}(\mathrm{M} 1), 1.510^{-3} \mathrm{~s}^{-1}(\mathrm{M} 2)$ and $6.010^{-3} \mathrm{~s}^{-1}(\mathrm{M} 3)$. Thus, the diffusion rate to the surface via external film or through the internal pores is much rapid than the NA sorption rate onto the magnetite surface. Thus, the intrinsic chemical reactions on the surface of iron oxide are likely to be the rate-limiting step.

Interparticle diffusion in NA sorption was determined experimentally by ultrasonic mixing which was employed to disperse loosely formed aggregates in the aqueous phase. In this case, the sorption rate should be faster if the interparticle diffusion is the rate-controlling step [22, $25,31]$. Sorption data with ultrasonication is in agreement with that of magnetic stirring which suggests that interparticle diffusion is not the rate-limiting step. Mass balance on solidand aqueous-phase NA was determined in every case which suggests that NA was removed only by sorption and not by molecular transformation or other phenomena.

Effect of initial concentration and solution chemistry on NA sorption: Sorption isotherms were determined and fitted to the Langmuir, Freundlich and Tempkin equations by applying linear regression analysis. As observed by the statistic analysis, best fitting of curves was found with Freundlich isotherm at the tested range of concentration of the solute (Fig. 2b). Following form of the Freundlich equation was employed:

$q_{e}=K_{F} C_{e}^{1 / n}$

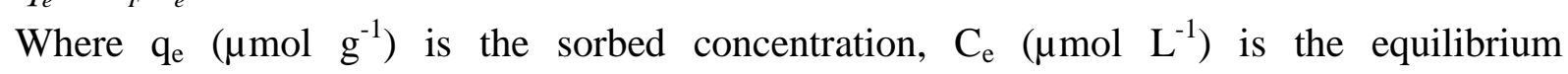
concentration at the end of the experiment, while $\mathrm{K}_{\mathrm{F}}$ and $\mathrm{n}$ are the Freundlich constants. Heterogeneity factor (n) can characterize this expression and thus, the heterogeneous systems can be described by Freundlich isotherm. Determination of Freundlich constants is enabled by plotting $\log C_{\mathrm{s}}$ versus $\log C_{\mathrm{e}}$ (Table 2). The Freundlich exponents are much smaller than unity for all solids. On the basis of sorption coefficients, the order of NA affinity was M1 > M2 > 
M3 (Table 2). Solid phase extraction showed a good mass balance, indicating the sole process was NA sorption without any molecular transformation on the surface of magnetite.

The observed sorption behaviour vs. $\mathrm{pH}$ can be linked to a blend of $\mathrm{pH}$-dependent NA speciation and the surface charge properties of the iron oxides (Fig. 2c). The adsorption envelope of monoprotic organic acids attached to iron oxide by inner sphere surface complexation usually represented highest adsorption at a $\mathrm{pH}$ near the $\mathrm{pK}_{\mathrm{a}}(\mathrm{pKa}$ of $\mathrm{NA}=5.95)$ $[21,26,32]$. An increase in NA sorption onto hydrous oxides was found firstly with an increase in $\mathrm{pH}$, where $\mathrm{NA}$ is protonated and particles of Fe-oxide contained positive charge. Charge repulsion was expected at $\mathrm{pH}$ above 7 where both sorbent and sorbate were negatively charged.

The effect of sodium chloride $(\mathrm{NaCl})$ addition at various ionic strengths (ranging from 0.001 to $1 \mathrm{M}$ ) was tested at $20{ }^{\circ} \mathrm{C}$ and $\mathrm{pH} 6.5$ (data not shown). Increasing the concentration of monovalent cation caused a slight decrease in sorption (less than 5\% for M1 and about $8 \%$ for M2 and M3) which suggested a stronger sorption mechanism of NA onto the surface of iron oxides than non-specific electrostatic interactions. Moreover, according to coagulation theory, cations should enhance particle aggregation which increases with an increase in ionic strength or $\mathrm{NaCl}$ concentration. As the ionic strength effect is less significant, the particle aggregation state must be of less importance. However, sorption of NA was highly decreased with an increase in phosphate concentration and completely inhibited at $1 \mathrm{mM}$ (data not shown). Indeed, the presence of a strong binding ligand such as phosphate hinders the surface sites of the sorbent and thus no NA sorption will occur.

FTIR data interpretation: The FTIR spectra of NA sorbed on magnetites were plotted only in the wavenumbers ranging from 1300 to $1800 \mathrm{~cm}^{-1}$ (Fig. 3). The vibration band assignments of the IR spectrum of the pure NA made by Gunasekaran and co-workers [33] were used here to interpret the IR spectra. Firstly, the carboxylic acid C-O stretching band (around $1327 \mathrm{~cm}^{-1}$ ) was shifted to $1375 \mathrm{~cm}^{-1}$ when NA is sorbed on M1 (Fig. 3). Strong bands at $1712 \mathrm{~cm}^{-1}$ and $1675 \mathrm{~cm}^{-1}$ are assigned for $\mathrm{C}=\mathrm{O}$ carbonyl stretching and $\mathrm{C}=\mathrm{O}$ carboxylic acid stretching, respectively [33]. These two vibration bands shifted to $1745 \mathrm{~cm}^{-1}$ and $1711 \mathrm{~cm}^{-1}$ after NA adsorption on M1 (Fig. 3). This shift could be linked to a coordination bond formed between the $\mathrm{C}=\mathrm{O}$ group and the $\mathrm{Fe}$ site or to the hydrogen bonding between the carbonyl and hydroxyl groups on the surface of magnetite. Slight shift to high wavenumbers was also observed after adsorption onto magnetite (Fig. 3) for the bands attributed to $C=C(1560,1617,1456$ and 
$\left.1544 \mathrm{~cm}^{-1}\right)$ and $\mathrm{C}=\mathrm{N}\left(1385,1473,1409\right.$ and $\left.1519 \mathrm{~cm}^{-1}\right)$ stretching vibrations [33]. All these observations confirm the presence of strong chemical interactions involved in the adsorption of NA on magnetite. Wu and co-workers [34] have analyzed the NA sorption onto clays by FTIR and reported that NA adsorption took place via a coordination bond formed between the keto oxygen and/or the $\mathrm{C}-\mathrm{N}$ group in the pyridine ring and the montmorillonite surface, while electrostatic and hydrophobic interactions are rather dominant during sorption of NA onto kaolinite.

The spectrum of NA sorbed on M2 in the $1300-1800 \mathrm{~cm}^{-1}$ was close to that of the M1 except that the absorption bands are less intense, suggesting the occurrence of similar interactions on both nanosized magnetites. However, the spectrum of NA sorbed on the microsized magnetite (M3) exhibits broader and lesser intense bands with a slight shift for the main bands. Lower sorption on M3 makes it difficult to describe accurately the NA surface speciation.

\subsection{Column study}

Breakthrough curves and sorption capacity in column. Firstly, column breakthrough curves (BTC) of bromide were established for all column tests and found nearly identical. High recovery rate of injected bromide (97\%) indicates mass conservation and an inert nature of the interactions between iron oxides and bromide. Flow is considered homogeneous as the mobile fraction is around $90 \%$. Macroscopic dispersivity of the medium was calculated by using the ratio between the dispersion coefficient $\left(D_{m}\right)$ and the pore velocity. Molecular diffusion was considered negligible with respect to the dynamic dispersion. Indeed, effective molecular diffusion coefficient is around $10^{-6} \mathrm{~cm}^{2} / \mathrm{s}$ which generally decreased with an increase in aqueous solubility. The calculated $D_{m}$ lies at $0.002 \mathrm{~cm}^{2} / \mathrm{min}$, while the dispersivity $\lambda$ was around $200 \mu \mathrm{m}$, close to the grain size particle. The Péclet number $(\mathrm{Pe}=\nu \mathrm{L} / \mathrm{D})$ was higher than 300 in the column, indicating the predominance of a convective regime in all column tests.

The BTC of NA from the three packed columns at a flow rate of $0.2 \mathrm{ml} . \mathrm{min}^{-1}$ are presented in Figure 4. The breakthrough point, curve steepness and the complete breakthrough strongly depend on the type of magnetite employed. For instance, the breakthrough point for NA in M1 column starts at $\sim 35 \mathrm{PV}$ and is completed at $\sim 60 \mathrm{PV}$, while for M2 the complete breakthrough occurred at around $30 \mathrm{PV}$ (Fig. $4 \mathrm{a} ; \mathrm{C}_{0}=50 \mu \mathrm{M}$ ). The $\mathrm{pH}$ of inflow solution of NA was around 6.0. But an increase in $\mathrm{pH}$ of outflow solution $\mathrm{H}$ was observed from about 5.0 to about 5.5 and slowly followed NA breakthrough throughout experiment (not shown). 
Maximum coincidence of the $\mathrm{pH}$ was observed with the breakthrough slope of NA. Influent value of $6 \pm 0.1$ was only regained when steady state was attained by solute sorption and complete breakthrough (data not shown).

The adsorption front in the BTC of M1 is diffuse, thereby underscoring the effect of kinetic, nonlinear sorption and/or physical dispersion. Shape of the isotherm might be reflected by this diffuse adsorption front when chemical equilibrium was achieved on the time scale of the column tests. For instance, a concave isotherm involves diffuse adsorption front in the sand packed column [35]. Present study provides a proper description of the sorption isotherms with the Freundlich model (Table 2, where the Freundlich exponents are much smaller than unity).

Sorbed amount in column was determined by calculating the total area above the breakthrough curve, which represents the amount of solute sorbed by the solid mass from the break point to complete breakthrough. The sorbed amounts determined at complete breakthrough for all the columns are reported in Table 3. The BTC were determined at a lower flow rate to ensure a high residence time and to reach local equilibrium in the column.

Comparison between the sorbed amounts for both methods represents a discrepancy between batch and column data. This may come in part from the leaching of Fe reactive species from the column or the loss of sorbent particles. To determine if the reactive phases were flushed out of the column, Fe content was analyzed in the effluent of columns blank test injected with background electrolyte (without NA). In case of M3 (microsized magnetite), total Fe was found very low corresponding to less than $2 \mathrm{mg}$ of magnetite in the effluent $(<1 \%)$. For M1 or M2, the total amounts of mobilized Fe would correspond to about $10 \%$ of magnetite present in the column. Nanoparticles can be flushed out of the column, thus reduce slightly the sorption capacity of the column system. However, further measurements showed that injection of NA can enhance particle mobilization, as more Fe was observed in the effluent of columns fed with NA solution. Therefore, mobilization of magnetite particles upon both water saturation and NA solution injection involved a slight fall in sorption observed in the flow system.

To confirm this behavior, BTCs for three M columns were evaluated according to the previous tests but by using fluoride as a reactive tracer. Fluoride was chosen as a model compound because of large amount of literature describing the interactions of fluoride with iron oxides [36]. The breakthrough finds represented a slight disparity between batch and 
column data. This observation pointed out the direct relation of such behavior with the loss of nanoparticles from the column, and not to the specific interactions of NA with oxide.

The retardation factor is important to characterize the transport of a solute in the convectiondispersion model. The retardation factor is concentration-independent in case of linear sorption. For nonlinear sorption, the retardation factor is concentration-dependent. Batch experiments can be used to determine retardation factors. The distribution coefficient $\mathrm{K}_{\mathrm{d}}$ and the retardation factor $\mathrm{R}$ can be linked as:

$$
R=1+\frac{\rho}{\theta} K_{d}
$$

Where $\rho$ is the bulk density $\left(\mathrm{g} / \mathrm{cm}^{3}\right), \theta$ the volumetric water content, and $\mathrm{K}_{\mathrm{d}}$ the sorption distribution coefficient $\left(\mathrm{cm}^{3} / \mathrm{g}\right)$.

For the Freundlich isotherm, the partition coefficient can be given by:

$$
\frac{\delta q_{e}}{\delta C}=K_{F} \frac{1}{n} C^{1 / n-1}=K_{d}
$$

and the retardation factor is given as $[37,38]$ :

$$
R=1+\frac{\rho}{\theta} K_{F} \frac{1}{n} C^{1 / n-1}
$$

The retardation factors estimated from eq.10 are reported in Table 4. The retardation factors for NA were also determined from moment analysis of the experimental BTC by assuming that sorption equilibrium was attained in the column system, and are presented in Table 4. As for the sorbed amounts, there is a disparity between the $\mathrm{R}$ values estimated from batch and column data.

Modeling of breakthrough capacities in column. Semi-empirical models such as the Thomas, Yan and Yoon-Nelson models are used to estimate the sorption extent under flow through conditions and to assess the breakthrough capacity from the break through curves.

The Thomas model is usually employed to estimate the extent and rate constant of sorption $[39,40]$. This model assumes that the external as well as the internal diffusions do not act as limiting step, as it is demonstrated above in our tested systems. However, Thomas model assumes the Langmuir isotherm for equilibrium and a second order reaction for kinetics [39], while Freundlich isotherm provides a good description of our sorption isotherms.

Expression of model in linear form gives: 


$$
\ln \left(\frac{C_{0}}{C}-1\right)=\frac{k_{T} q_{e} m}{Q}-\frac{k_{T} C_{0} V}{Q}
$$

where $k_{\mathrm{T}}$ is the Thomas rate constant $\left(\mathrm{ml} \mathrm{min}^{-1} \mu \mathrm{mol}^{-1}\right), q_{\mathrm{e}}$ is the equilibrium sorbed per $\mathrm{g}$ of the sorbent $\left(\mu \mathrm{mol} \mathrm{g}{ }^{-1}\right), Q$ is the volumetric flow rate $\left(\mathrm{ml} \mathrm{min}^{-1}\right), V$ is the effluent volume $(\mathrm{ml})$ and $m$ is the sorbent mass in column $(\mathrm{g})$. A linear plot of $\ln \left[\left(C_{0} / C\right)-1\right]$ against $V / Q$ (or $t$ ) allows to determine $k_{\mathrm{T}}$ and $q_{\mathrm{e}}$ values from the intercept and the slope of the plot, respectively. Poor $r^{2}$ values were achieved by the Thomas model, suggesting an inaccurate description of all breakthrough data by the said model (Table 3 ). In spite of the poor $r^{2}$ values, sorbed amount predicted by the Thomas model is in relatively good agreement with sorption capacities calculated by integrating the total area above the BTC (Table 3). The values of $K_{\mathrm{T}}$ and $q_{\mathrm{e}}$ were affected by influent concentration: $q_{\mathrm{e}}$ increased while $k_{T}$ decreased with increasing influent concentration of NA.

The Yan model is an empirical model that can overcome the Thomas model deficiency in predicting the concentration at $\mathrm{t}=0$ [41]. The Yan model is supposed to provide more accurate description of different parts of the BTC [42]. Experimental data can be fitted through the following equation:

$$
\frac{C}{C_{0}}=1-\frac{1}{1+\left(\frac{V}{d}\right)^{a}}
$$

Where a and $\mathrm{d}$ are the constants of the Yan model, with $\mathrm{d}=\mathrm{q}_{\mathrm{y}} \mathrm{m} / \mathrm{C}_{0}$ and $\mathrm{a}=\mathrm{k}_{\mathrm{y}} \mathrm{C}_{0} / \mathrm{Q} ; k_{Y}=$ kinetic rate constant for the Yan model $\left(\mathrm{ml} \mathrm{min}^{-1} \mu \mathrm{mol}^{-1}\right)$, and $q_{y}=$ maximum adsorption capacity $\left(\mu \mathrm{mol} \mathrm{g}^{-1}\right)$ of the adsorbent estimated by the Yan model.

Yan model yielded satisfactory values of $r^{2}$ suggesting that it can accurately describe all breakthrough data (Table 3). A good agreement was observed between the predicted sorbed amount and the sorption capacity (Table 3). As for the Thomas model, the values of Yan model parameters depend on the influent concentration: $k_{Y}$ decreased with increasing influent concentration of NA.

The Yoon-Nelson model was also employed as a descriptive model [43]. This model in linearized form for a single component system is described as:

$$
\ln \left(\frac{C}{C_{0}-C}\right)=k_{Y N} t-\tau k_{Y N}
$$


where $k_{\mathrm{YN}}$ is the Yoon-Nelson rate constant $\left(\mathrm{min}^{-1}\right.$ ), and $\tau$ is the time required for $50 \%$ adsorbate breakthrough. The Yoon-Nelson model gives the poorest $r^{2}$ values, and therefore it is not considered in the calculation of BTC.

BTCs were only calculated with Thomas and Yann models using the fitting parameters, and are presented as solid lines in Figures 4 and 5. Both Yan and Thomas model fit relatively well the breakthrough curves of NA adsorption, but the best fitting was obtained with the Yan model (Fig. 5). Calculated and experimental BTC were in good agreement with each other for all magnetites. Thomas model failed particularly to predict an accurate concentration at lower and higher time points of the BTC, especially for M2 (Fig.4).

\section{Conclusions}

Particle size and surface properties of tested magnetite strongly affected the kinetics and extent of NA sorption. The kinetic sorption experiments showed that apparent rate constant normalized to solid mass, is faster for the nanosized magnetite while an opposite trend was observed for the surface area-normalized rate constants. The aggregation state of the particles did not affect the sorption extent or rate. FTIR data suggested that similar surface interactions occurred on both microsized and nanosized magnetites. Experimental and modeling data suggested that transport of NA under flow through conditions was linked to the instantaneous sorption and no significant impact of chemical kinetic limitation was observed. Less than $10 \%$ of nanoparticles can be flushed out of the column, thereby resulting in slight decrease in sorption capacity of the column system. Three semi-empirical models Thomas, Yoon-Nelson and Yan models were employed to estimate the amount of NA sorbed in the column. The sorbed amount predicted by Thomas or Yan model was in good agreement with sorption capacities calculated by integrating the total area above the BTC. However, Thomas model failed particularly to predict accurately the concentration at lower and higher time points of the BTC, especially for M2. These findings have strong implications in relation to transport and removal of environmental pollutants in natural and engineered systems.

\section{Acknowledgements}

The authors gratefully acknowledge the financial support provided by CNRS (Centre Nationale de la Recherche Scientifique) of France and Higher Education Commission (HEC) of Pakistan. 


\section{References}

[1] U. Schwertmann, R.M. Cornell, Iron Oxides in the Laboratory: Preparation and Characterization, Wiley-VCH, New York, 2000.

[2] M. Usman, P. Faure, C. Ruby, K. Hanna, Remediation of PAH-contaminated soils by magnetite catalyzed Fenton-like oxidation, Appl. Catal. B: Environ. 117-118 (2012) 10-17.

[3] M. Usman, P. Faure, C. Lorgeoux, C. Ruby, K. Hanna, Treatment of hydrocarbon contamination under flow through conditions by using magnetite catalyzed chemical oxidation, Environ. Sci. Pollut. Res. 20 (2013) 22-30.

[4] G. Sposito, The chemistry of soils, Oxford university press, 2008.

[5] X. Xue, K. Hanna, M. Abdelmoula, N. Deng, Adsorption and oxidation of PCP on the surface of magnetite: Kinetic experiments and spectroscopic investigations, Appl. Catal. B: Environ. 89 (2009) 432-440.

[6] R. Karlin, M. Lyle, G.R. Heath, Authigenic magnetite formation in suboxic marine sediments, Nature, 326 (1987) 490-493.

[7] B.A. Maher, R.M. Taylor, Formation of ultrafine-grained magnetite in soils, Nature, 336 (1988) 368-370.

[8] C.-Y. Peng, G.V. Korshin, R.L. Valentine, A.S. Hill, M.J. Friedman, S.H. Reiber, Characterization of elemental and structural composition of corrosion scales and deposits formed in drinking water distribution systems, Water Res. 44 (2010) 4570-4580.

[9] P. Sarin, V.L. Snoeyink, J. Bebee, W.M. Kriven, J.A. Clement, Physico-chemical characteristics of corrosion scales in old iron pipes, Water Res. 35 (2001) 2961-2969.

[10] A. Zegeye, M. Abdelmoula, M. Usman, K. Hanna, C. Ruby, In situ monitoring of lepidocrocite bioreduction and magnetite formation by reflection Mossbauer spectroscopy, Am. Mineral. 96 (2011) 1410-1413.

[11] C. Ruby, M. Usman, S. Naille, K. Hanna, C. Carteret, M. Mullet, M. François, M. Abdelmoula, Synthesis and transformation of iron-based layered double hydroxides, Appl. Clay Sci. 48 (2010) 195-202.

[12] M. Usman, M. Abdelmoula, K. Hanna, B. Grégoire, P. Faure, C. Ruby, FeII induced mineralogical transformations of ferric oxyhydroxides into magnetite of variable stoichiometry and morphology, J. Solid State Chem. 194 (2012) 328-335.

[13] M. Usman, M. Abdelmoula, P. Faure, C. Ruby, K. Hanna, Transformation of various kinds of goethite into magnetite: Effect of chemical and surface properties, Geoderma, 197198 (2013) 9-16.

[14] S.R. Chowdhury, E.K. Yanful, Arsenic and chromium removal by mixed magnetitemaghemite nanoparticles and the effect of phosphate on removal, J. Environ. Manag. 91 (2010) 2238-2247.

[15] M. Martínez, J. Giménez, J. de Pablo, M. Rovira, L. Duro, Sorption of selenium(IV) and selenium(VI) onto magnetite, Appl. Surf. Sci. 252 (2006) 3767-3773.

[16] S. Dixit, J.G. Hering, Comparison of Arsenic(V) and Arsenic(III) Sorption onto Iron Oxide Minerals: Implications for Arsenic Mobility, Environ. Sci. Technol., 37 (2003) 41824189.

[17] T. Missana, M. García-Gutiérrez, V. Fernńdez, Uranium (VI) sorption on colloidal magnetite under anoxic environment: experimental study and surface complexation modelling, Geochim. Cosmochim. Acta. 67 (2003) 2543-2550. 
[18] T. Missana, U. Alonso, A.C. Scheinost, N. Granizo, M. García-Gutiérrez, Selenite retention by nanocrystalline magnetite: Role of adsorption, reduction and dissolution/coprecipitation processes, Geochim. Cosmochim. Acta. 73 (2009) 6205-6217.

[19] A. Scheidegger, M. Borkovec, H. Sticher, Coating of silica sand with goethite: preparation and analytical identification, Geoderma, 58 (1993) 43-65.

[20] K. Hanna, Adsorption of aromatic carboxylate compounds on the surface of synthesized iron oxide-coated sands, Appl. Geochem. 22 (2007) 2045-2053.

[21] E. Tanis, K. Hanna, E. Emmanuel, Experimental and modeling studies of sorption of tetracycline onto iron oxides-coated quartz, Coll. Surf. A. 327 (2008) 57-63.

[22] K. Hanna, B. Rusch, L. Lassabatere, A. Hofmann, B. Humbert, Reactive transport of gentisic acid in a hematite-coated sand column: Experimental study and modeling, Geochim. Cosmochim. Acta. 74 (2010) 3351-3366.

[23] E. Clervil, M. Usman, E. Emmanuel, V. Chatain, K. Hanna, Sorption of nalidixic acid onto sediments under batch and dynamic flow conditions, Chem. Geol. 335 (2013) 63-74.

[24] B. Rusch, K. Hanna, B. Humbert, Sorption and Transport of Salicylate in a Porous Heterogeneous Medium of Silica Quartz and Goethite, Environ. Sci. Technol. 44 (2010) 2447-2453.

[25] K. Hanna, L. Lassabatere, B. Bechet, Transport of two naphthoic acids and salicylic acid in soil: Experimental study and empirical modeling, Water Res. 46 (2012) 4457-4467.

[26] K. Hanna, J.F. Boily, Sorption of two naphthoic acids to goethite surface under flow through conditions, Environ. Sci. Technol. 44 (2010) 8863-8869.

[27] Z.-X. Sun, F.-W. Su, W. Forsling, P.-O. Samskog, Surface Characteristics of Magnetite in Aqueous Suspension, J. Colloid Interf. Sci. 197 (1998) 151-159.

[28] C.T. Chiou, L.J. Peters, V.H. Freed, A Physical Concept of Soil-Water Equilibria for Nonionic Organic Compounds, Science, 206 (1979) 831-832.

[29] T.K. Sherwood, R.L. Pigford, C. Wilke, Mass Transfer, McGraw-Hill, New York, 1975.

[30] O. Levenspiel, Chemical Reaction Engineering, Second ed., Wiley-Eastern Limited, New York, 1972.

[31] K. Hanna, F. Quilès, Surface Complexation of 2,5-Dihydroxybenzoic Acid (Gentisic Acid) at the Nanosized Hematite-Water Interface: An ATR-FTIR Study and Modeling Approach, Langmuir, 27 (2011) 2492-2500.

[32] K. Hanna, Sorption of two aromatic acids onto iron oxides: Experimental study and modeling, J. Colloid Interf. Sci. 309 (2007) 419-428.

[33] S. Gunasekaran, R.K. Natarajan, R. Rathikha, D. Syamala, Vibrational spectra and normal coordinate analysis of nalidixic acid, Indian J. Pure Ap. Phy. 43 (2005) 503-508.

[34] Q. Wu, Z. Li, H. Hong, Adsorption of the quinolone antibiotic nalidixic acid onto montmorillonite and kaolinite, Appl. Clay Sci. 74 (2013) 66-73.

[35] C.S. Bürglsser, M. Černík, M. Borkovec, H. Sticher, Determination of nonlinear adsorption isotherms from column experiments: An alternative to batch studies, Environ. Sci. Technol. 27 (1993) 943-948.

[36] L. Sigg, W. Stumm, The interaction of anions and weak acids with the hydrous goethite $(\alpha-\mathrm{FeOOH})$ surface, Colloid. Surface. 2 (1981) 101-117.

[37] C. Zheng, G.D. Bennett, Applied Contaminant Transport Modeling, 2nd ed., Wiley and Sons, Inc., New York, 2002.

[38] H.D. Sharma, K.R. Reddy, Geoenvironmental engineering: site remediation, waste containment, and emerging waste management technologies, John Wiley \& Sons, Inc., New Jersey, 2004.

[39] S. Srivastava, S. Harsh, A.K. Srivastava, Use of NADH fluorescence measurement for on-line biomass estimation and characterization of metabolic status in bioreactor cultivation 
of plant cells for azadirachtin (a biopesticide) production, Process Biochem. 43 (2008) 11211123.

[40] X. Martínez-Lladó, C. Valderrama, M. Rovira, V. Martí, J. Giménez, J. de Pablo, Sorption and mobility of $\mathrm{Sb}(\mathrm{V})$ in calcareous soils of Catalonia (NE Spain): Batch and column experiments, Geoderma, 160 (2011) 468-476.

[41] G. Yan, T. Viraraghavan, M. Chen, A new model for heavy metal removal in a biosorption column, Adsorpt. Sci. Technol. 19 (2001) 25-43.

[42] G. Yan, T. Viraraghavan, Heavy metal removal in a biosorption column by immobilized M. rouxii biomass, Bioresource Technol, 78 (2001) 243-249.

[43] Y.H. Yoon, J.H. Nelson, Application of gas adsorption kinetics I. A theoretical model for respirator cartridge service life, Am. Ind. Hyg. Assoc. J. 45 (1984) 509-516. 


\section{Tables}

Table 1. Main characteristics of three magnetites

\begin{tabular}{|l|l|l|l|l|l|}
\hline $\begin{array}{l}\text { Magnetite } \\
\text { samples }\end{array}$ & $\begin{array}{l}\text { Mean } \\
\text { particle size }\end{array}$ & $\begin{array}{l}\text { SSA GEO } \\
\left(\mathrm{m}^{2} \mathrm{~g}^{-1}\right)\end{array}$ & $\begin{array}{l}\text { SSA BET } \\
\left(\mathrm{m}^{2} \mathrm{~g}^{-1}\right)\end{array}$ & PZC & $P_{s}$ \\
\hline M1 & $30 \mathrm{~nm}$ & 38 & $103 \pm 2$ & 7.9 & 29.0 \\
\hline M2 & $60 \mathrm{~nm}$ & 19 & $25 \pm 1$ & 7.7 & 7.1 \\
\hline M3 & $1.5 \mu \mathrm{m}$ & 1.8 & $1.7 \pm 0.1$ & 7.4 & 0.5 \\
\hline
\end{tabular}

Table 2. Equilibrium and kinetic parameters obtained when the experimental data was fitted to the Freundlich isotherm and the pseudo-second order model.

\begin{tabular}{|c|c|c|c|c|c|c|}
\hline \multirow[b]{2}{*}{ Solid } & \multicolumn{3}{|c|}{ Kinetic parameters } & \multicolumn{3}{|c|}{ Equilibrium parameters } \\
\hline & $\begin{array}{c}q_{e} \\
\left(\mu \mathrm{mol} \mathrm{g}^{-1}\right)\end{array}$ & $\begin{array}{c}\mathrm{k}_{2} \\
\left(\mathrm{~g} \mu \mathrm{mol}^{-1}\right. \\
\left.\min ^{-1}\right)\end{array}$ & $r^{2}$ & $\mathrm{~K}_{\mathrm{F}}$ & $1 / \mathrm{n}$ & $r^{2}$ \\
\hline M1 & 172.4 & $1.85 \mathrm{E}-04$ & 0.9997 & $2.97 \mathrm{E}-02$ & 0.550 & 0.9954 \\
\hline M2 & 74.6 & $1.26 \mathrm{E}-03$ & 0.9998 & $9.80 \mathrm{E}-02$ & 0.766 & 0.9945 \\
\hline M3 & 16.0 & $2.22 \mathrm{E}-02$ & 0.9997 & $2.42 \mathrm{E}-03$ & 0.589 & 0.9889 \\
\hline
\end{tabular}


Table 3: Experimental sorbed amount in column and Thomas model parameters for NA sorption at tow feed concentrations: $50 \mu M$ and $200 \mu M$.

\begin{tabular}{|c|c|c|c|c|c|c|c|c|}
\hline \multirow[t]{3}{*}{ solid } & \multicolumn{2}{|c|}{$\begin{array}{l}\text { Sorption amount in } \\
\text { column }\left(\mu \mathrm{mol} \mathrm{g}{ }^{-1}\right)\end{array}$} & \multicolumn{6}{|c|}{ Thomas model } \\
\hline & \multirow[b]{2}{*}{$50 \mu M$} & \multirow[b]{2}{*}{$200 \mu M$} & \multicolumn{2}{|c|}{$\begin{array}{c}q_{e} \\
\left(\mu \mathrm{mol} \mathrm{g}{ }^{-1}\right)\end{array}$} & \multicolumn{2}{|c|}{$\begin{array}{c}\mathrm{k}_{\mathrm{th}} \\
\left(\mathrm{ml} \mu \mathrm{mol}^{-1} \min ^{-1}\right)\end{array}$} & \multicolumn{2}{|c|}{$\mathrm{r}^{2}$} \\
\hline & & & $50 \mu M$ & $200 \mu M$ & $50 \mu M$ & $200 \mu M$ & $50 \mu M$ & $200 \mu M$ \\
\hline M1 & 51.2 & 132.8 & 50.01 & 140.4 & 0.101 & 0.036 & 0.96 & 0.96 \\
\hline M2 & 26.7 & 55.6 & 27.7 & 58.5 & 0.138 & 0.041 & 0.92 & 0.91 \\
\hline M3 & 5.5 & 14.1 & 5.9 & 13.9 & 0.63 & 0.140 & 0.84 & 0.86 \\
\hline
\end{tabular}

Yan model parameters

\begin{tabular}{|c|c|c|c|c|c|c|}
\hline \multirow{2}{*}{ solid } & \multicolumn{5}{|c|}{ Yan model } \\
\cline { 2 - 7 } & $\begin{array}{c}k_{Y} \\
\end{array}$ & $\left.\mathbf{m l} \mu \mathrm{mol}^{-1} \mathrm{~min}^{-1}\right)$ & \multicolumn{2}{|c|}{$\begin{array}{c}\mathrm{q}_{\mathrm{y}} \\
(\mu \mathrm{mol} \mathrm{g})^{-1}\end{array}$} & \multicolumn{2}{c|}{$\mathrm{r}^{2}$} \\
\cline { 2 - 7 } & $\mathbf{5 0} \boldsymbol{\mu M}$ & $\mathbf{2 0 0} \boldsymbol{\mu M}$ & $\mathbf{5 0} \boldsymbol{\mu M}$ & $\mathbf{2 0 0} \boldsymbol{\mu M}$ & $\mathbf{5 0} \boldsymbol{\mu M}$ & $\mathbf{2 0 0} \boldsymbol{\mu M}$ \\
\hline M1 & $42.4 \mathrm{E}-03$ & $10.6 \mathrm{E}-03$ & 48.3 & 137.2 & 0.95 & 0.95 \\
\hline M2 & $34.8 \mathrm{E}-03$ & $9.4 \mathrm{E}-03$ & 27.0 & 60.0 & 0.97 & 0.95 \\
\hline M3 & $30.0 \mathrm{E}-03$ & $8.1 \mathrm{E}-03$ & 5.7 & 15.2 & 0.86 & 0.88 \\
\hline
\end{tabular}

Yoon-Nelson model parameters

\begin{tabular}{|c|c|c|c|c|c|c|}
\hline \multirow[t]{3}{*}{ solid } & \multicolumn{6}{|c|}{ Yoon-Nelson model } \\
\hline & \multicolumn{2}{|l|}{$\begin{array}{l}\tau \\
(\min )\end{array}$} & \multicolumn{2}{|l|}{$\begin{array}{l}\mathrm{k}_{\mathrm{YN}} \\
\left(\min ^{-1}\right)\end{array}$} & \multicolumn{2}{|l|}{$\mathrm{r}^{2}$} \\
\hline & $50 \mu M$ & $200 \mu M$ & $50 \mu M$ & $200 \mu M$ & $50 \mu M$ & $200 \mu M$ \\
\hline M1 & 2390 & 1684 & 0.0031 & 0.0044 & 0.88 & 0.88 \\
\hline M2 & 1273 & 756 & 0.0041 & 0.0084 & 0.92 & 0.90 \\
\hline M3 & 286 & 186 & 0.017 & 0.030 & 0.80 & 0.84 \\
\hline
\end{tabular}


Table 4: Retardation factors derived from batch and column tests

\begin{tabular}{|l|l|l|l|l|}
\hline \multirow{2}{*}{ Sorbent } & \multicolumn{2}{|c|}{ Batch } & \multicolumn{2}{c|}{ Column } \\
\cline { 2 - 5 } & $\mathbf{5 0} \boldsymbol{\mu M}$ & $\mathbf{2 0 0} \boldsymbol{\mu M}$ & $\mathbf{5 0} \boldsymbol{\mu M}$ & $\mathbf{2 0 0} \boldsymbol{\mu M}$ \\
\hline M1 & 60.9 & 33.1 & 41.0 & 29.0 \\
\hline M2 & 33.4 & 24.4 & 22.5 & 12.0 \\
\hline M3 & 4.6 & 3.1 & 4.9 & 3.3 \\
\hline
\end{tabular}




\section{Figures captions}

Figure 1: XRD (a) and TEM (b) of the three used magnetites (M1, M2 and M3).

Figure 2: (a) Sorption onto three $\mathrm{M} v s$. time. Solid=0.5 g/L; [NA] $=200 \mu \mathrm{M} ; \mathrm{pH}=6.5 \pm 0.1$. Lines represent kinetic model fits. (b) Sorption isotherms onto M1, M2 and M3. Solid= 0.5 $\mathrm{g} / \mathrm{L} ; \mathrm{pH}=6.5 \pm 0.1$. (c) Sorption onto three M vs. $\mathrm{pH}$. Solid= $0.5 \mathrm{~g} / \mathrm{L} ;[\mathrm{NA}]=50 \mu \mathrm{M}$. Conditions: $\mathrm{T}=20 \pm 1{ }^{\circ} \mathrm{C}, \mathrm{pH}=6.5 \pm 0.1, \mathrm{NaCl}(10 \mathrm{mM})$ was used as a supporting electrolyte.

Figure 3: FTIR of of NA sorbed on M1, M2 and M3. Solid= $0.5 \mathrm{~g} / \mathrm{L}$; $[\mathrm{NA}]=200 \mu \mathrm{M}, \mathrm{T}=$ $20 \pm 1{ }^{\circ} \mathrm{C}, \mathrm{pH}=6 \pm 0.1, \mathrm{NaCl}(10 \mathrm{mM})$ was used as a supporting electrolyte.

Figure 4: Experimental breakthrough curves of $\mathrm{Br}^{-}$and $\mathrm{NA}$; Flow rate $=0.2 \mathrm{~mL} / \mathrm{min}$. Experimental data (symbols) and calculated breakthrough curves (solid lines) by Thomas model. $0.5 \mathrm{~g}$ was the amount of reactive phase in each column test. Inflow solution with (a) $\mathrm{C}_{0}=50 \mu \mathrm{M} ;(\mathbf{b}) \mathrm{C}_{0}=200 \mu \mathrm{M} ; \mathrm{pH}=6 \pm 0.1 ; \mathrm{T}=20^{\circ} \mathrm{C}, \mathrm{NaCl}(10 \mathrm{mM}),\left[\mathrm{Br}^{-}\right]=10^{-2} \mathrm{M}$.

Figure 5: Experimental breakthrough curves of $\mathrm{Br}^{-}$and $\mathrm{NA}$; Flow rate $=0.2 \mathrm{~mL} / \mathrm{min}$. Experimental data (symbols) and calculated breakthrough curves (solid lines) by Yan model. $0.5 \mathrm{~g}$ was the amount of reactive phase in each column test. Inflow solution with (a) $\mathrm{C}_{0}=50$ $\mu \mathrm{M} ;(\mathbf{b}) \mathrm{C}_{0}=200 \mu \mathrm{M} ; \mathrm{T}=20^{\circ} \mathrm{C}, \mathrm{pH}=6 \pm 0.1 ; \mathrm{NaCl}(10 \mathrm{mM}),\left[\mathrm{Br}^{-}\right]=10^{-2} \mathrm{M}$. 
Fig. 1:

(a)

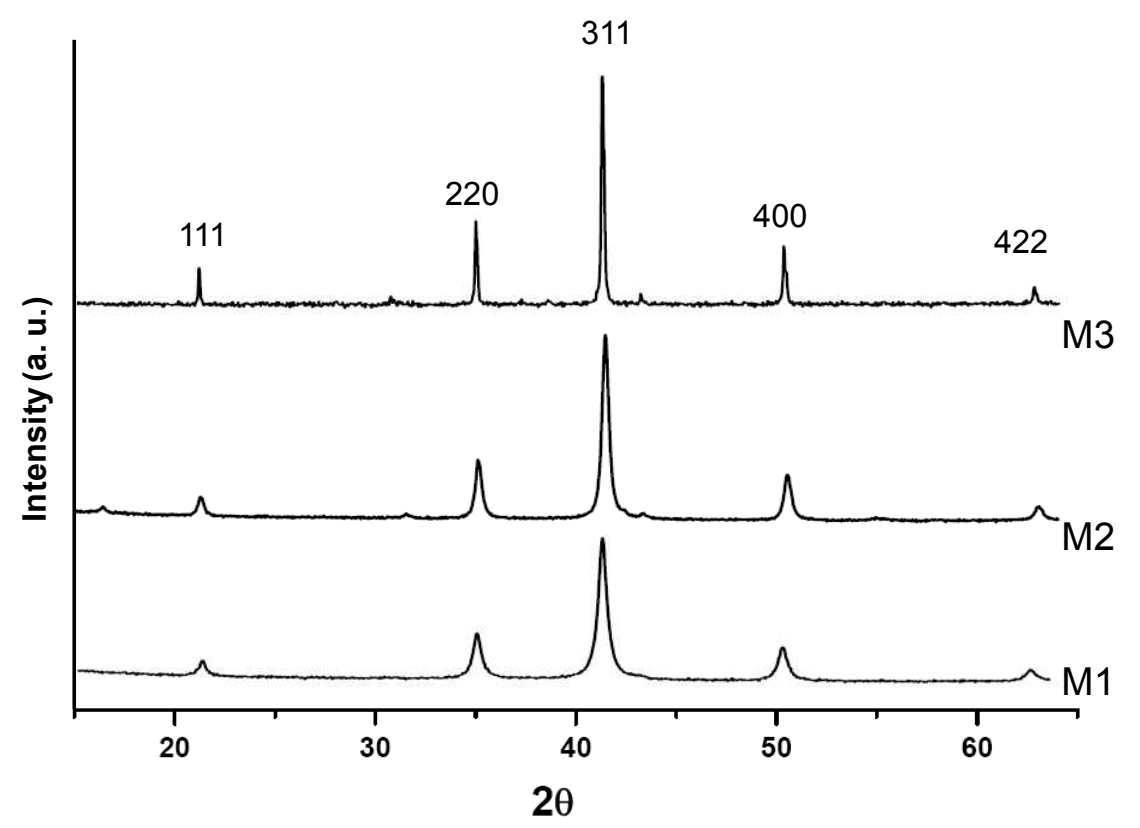

(b)
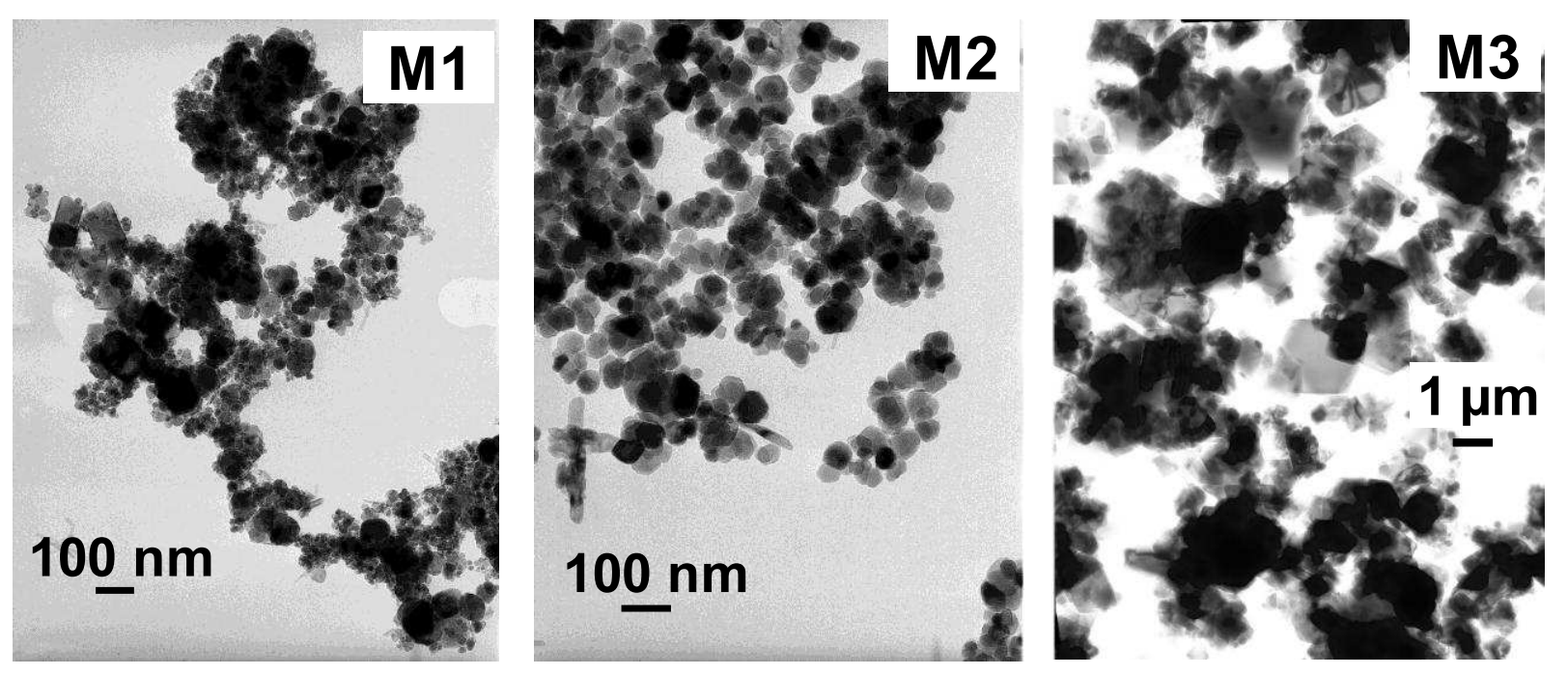
Fig. 2:

(a)

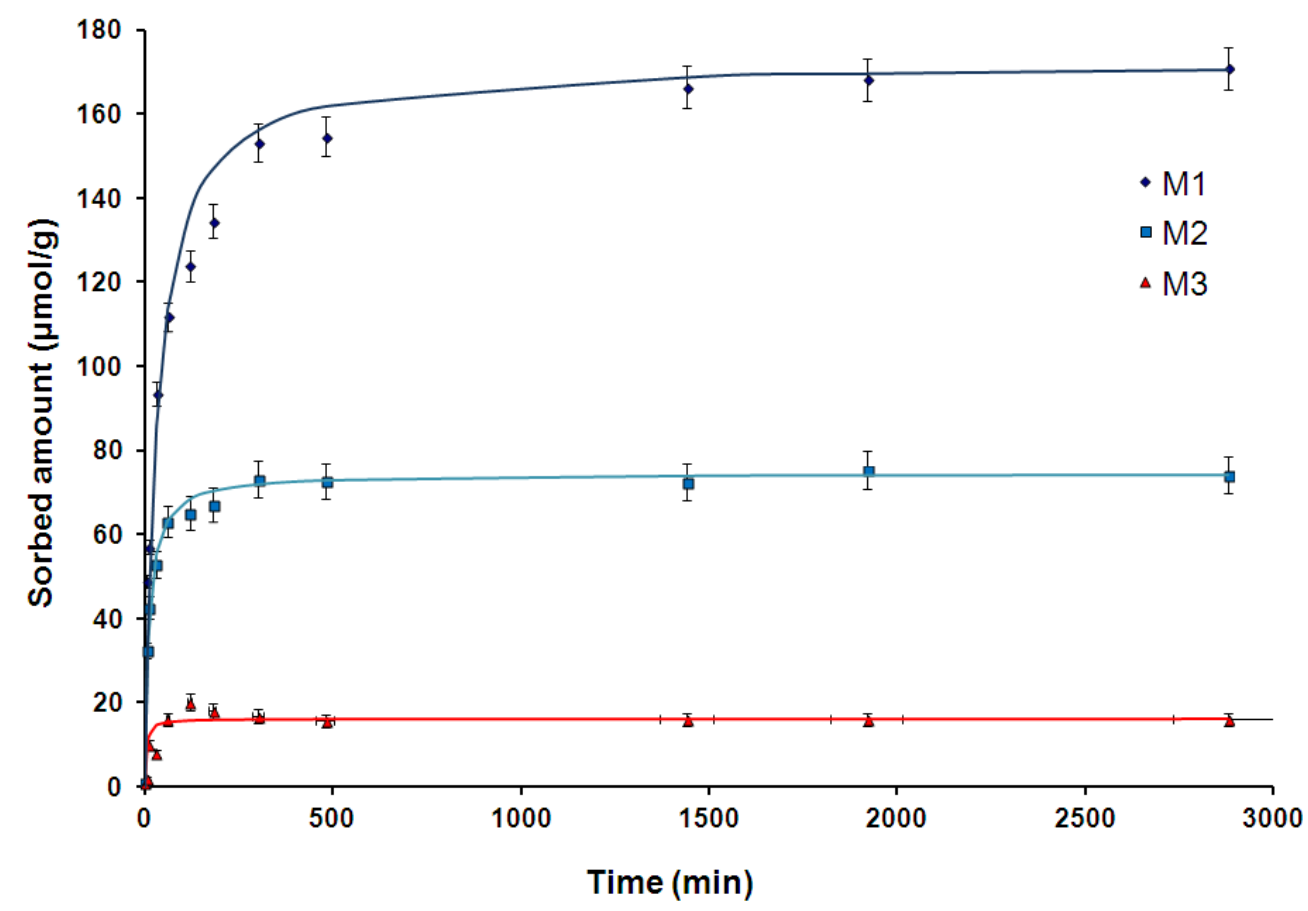

(b)

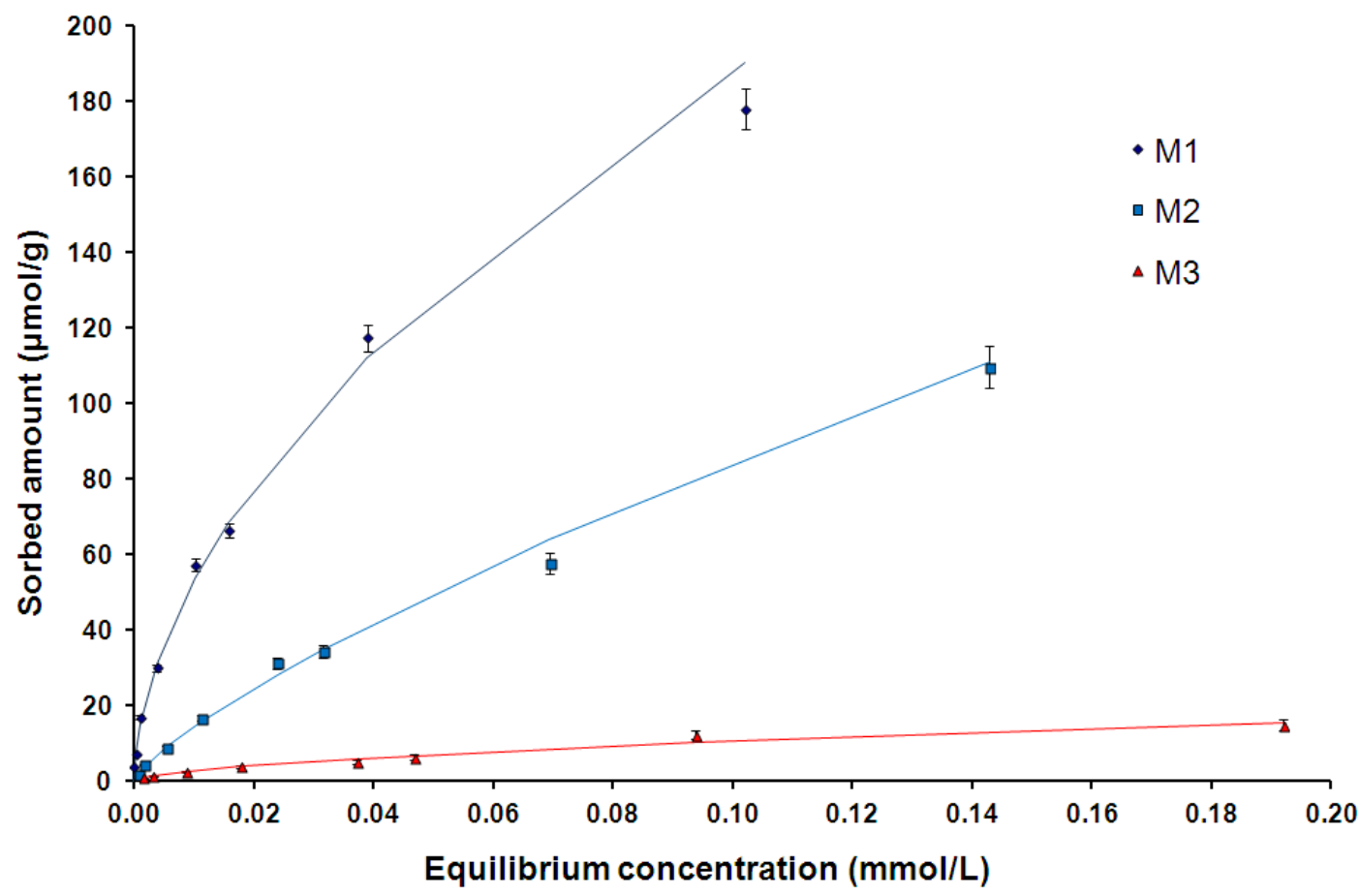


(c)

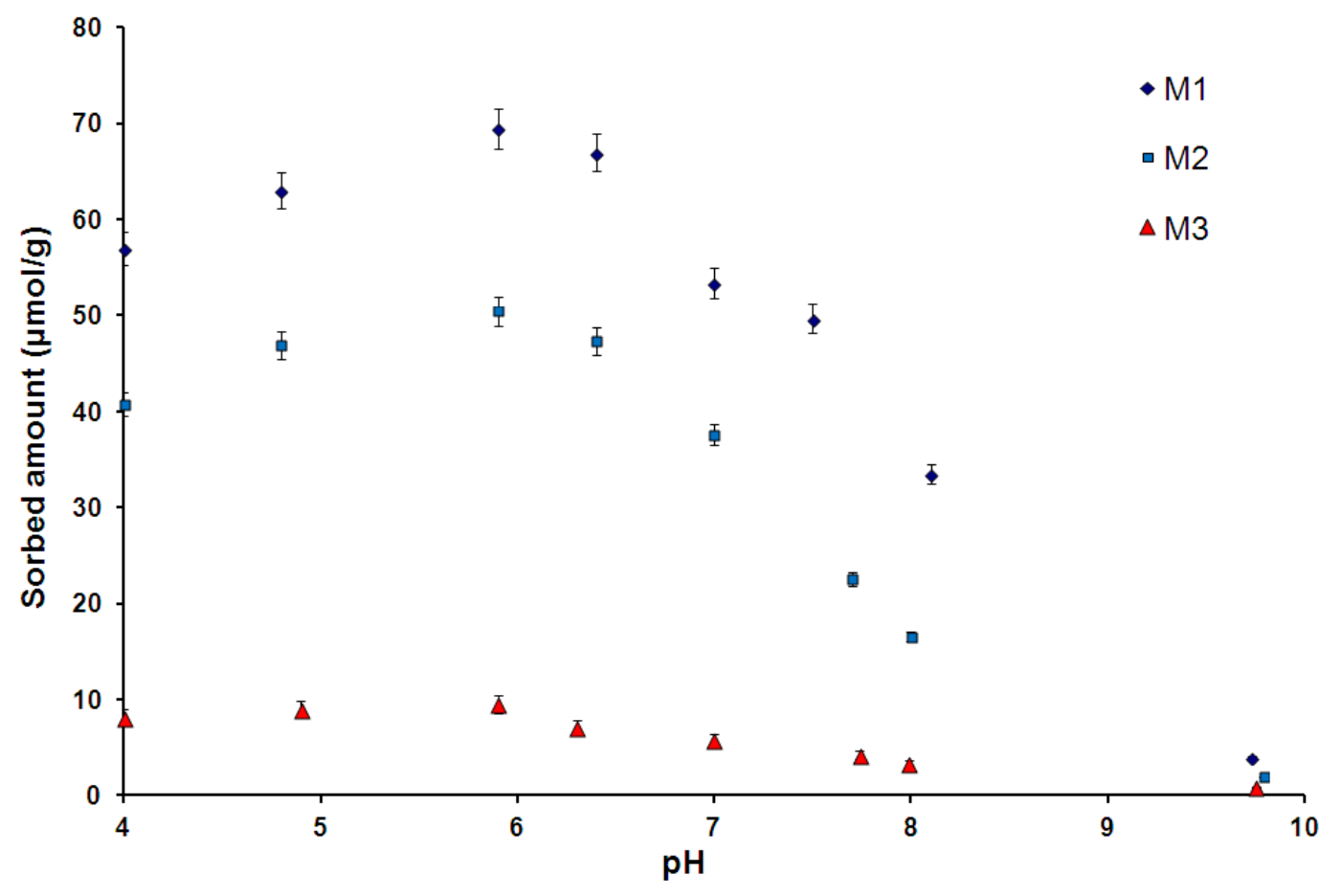


Fig. 3:

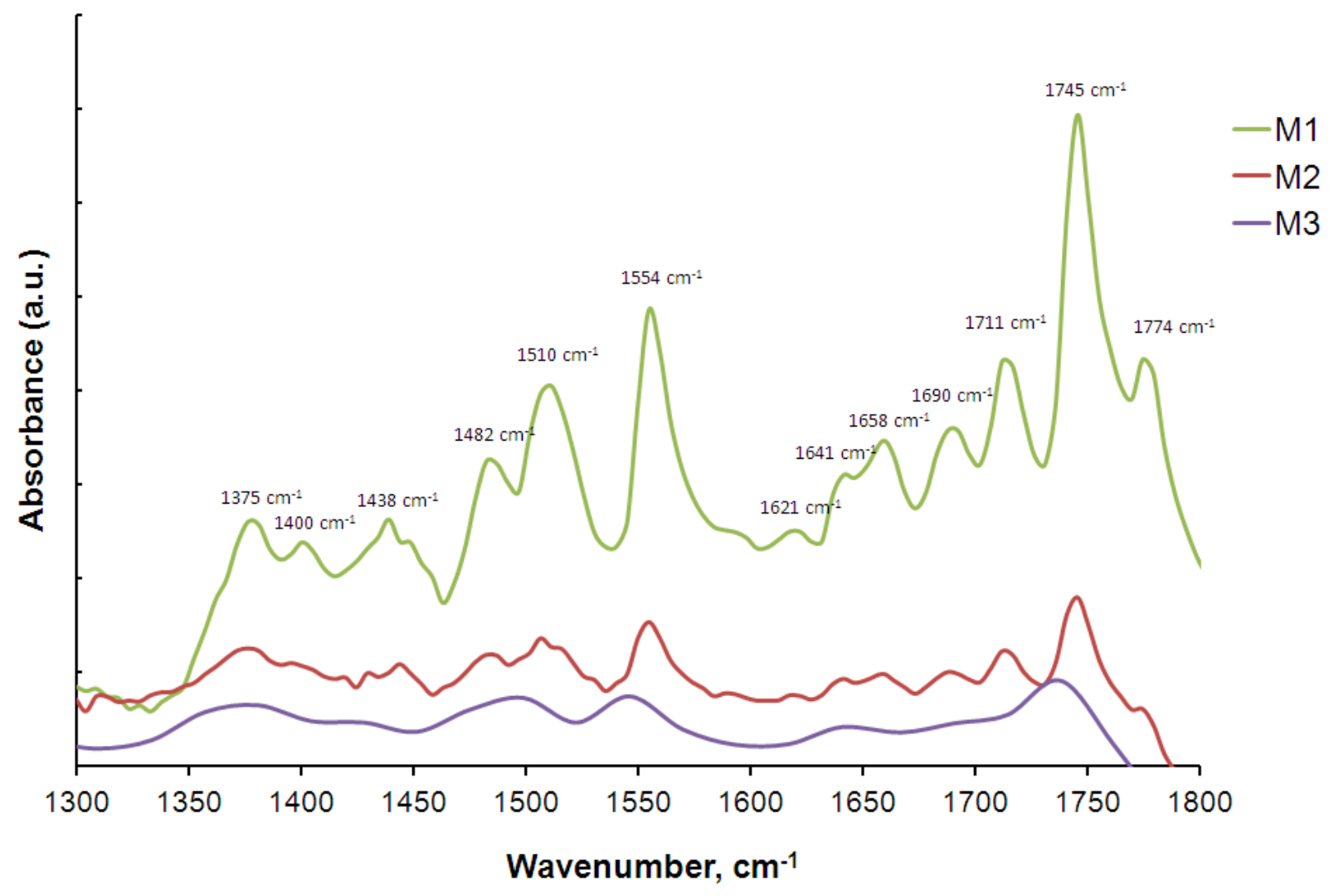


Fig. 4: (Thomas model)

(a) $\mathrm{C}_{0}=50 \mu \mathrm{M}$

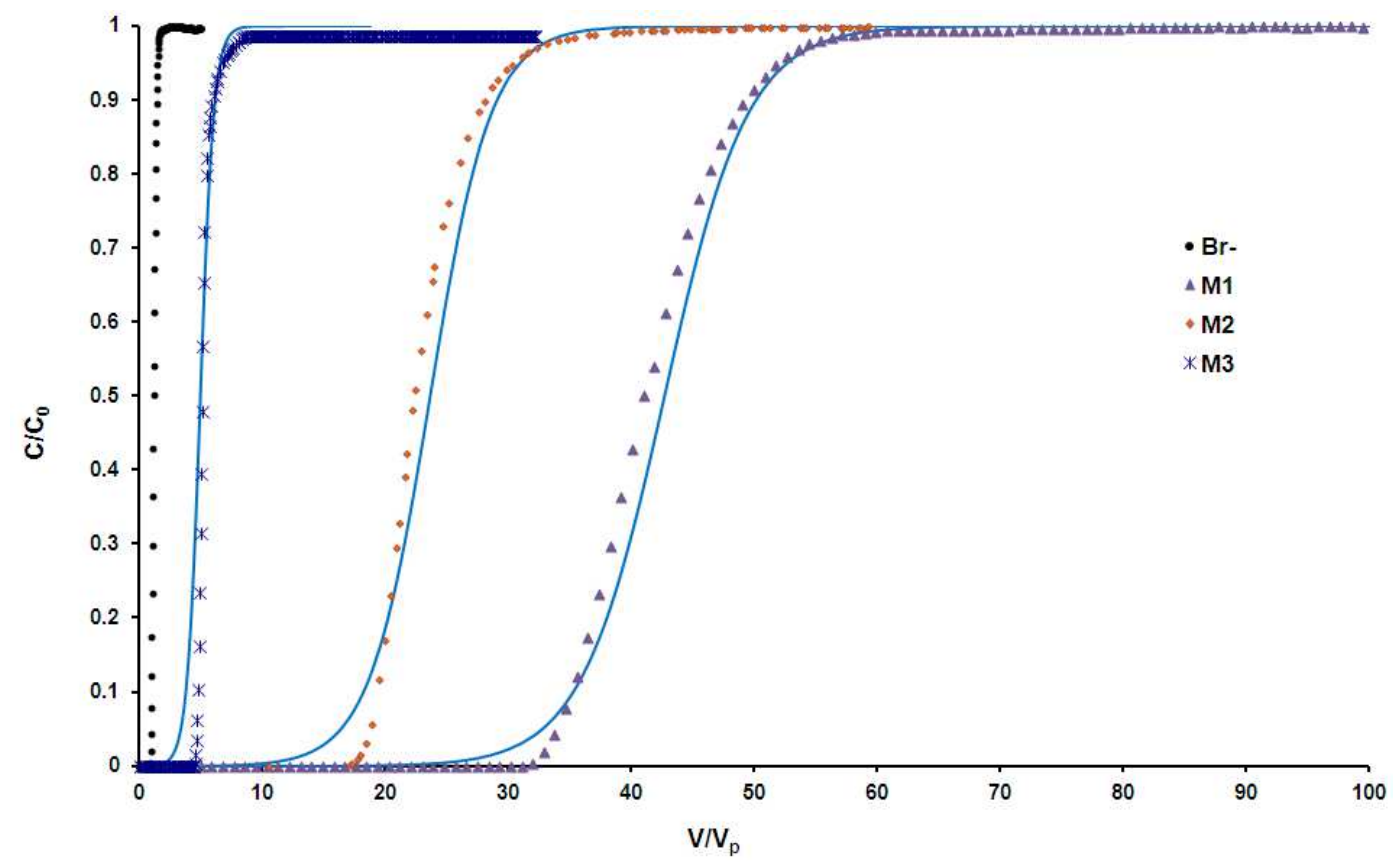

(b) $\mathrm{C}_{0}=200 \mu \mathrm{M}$

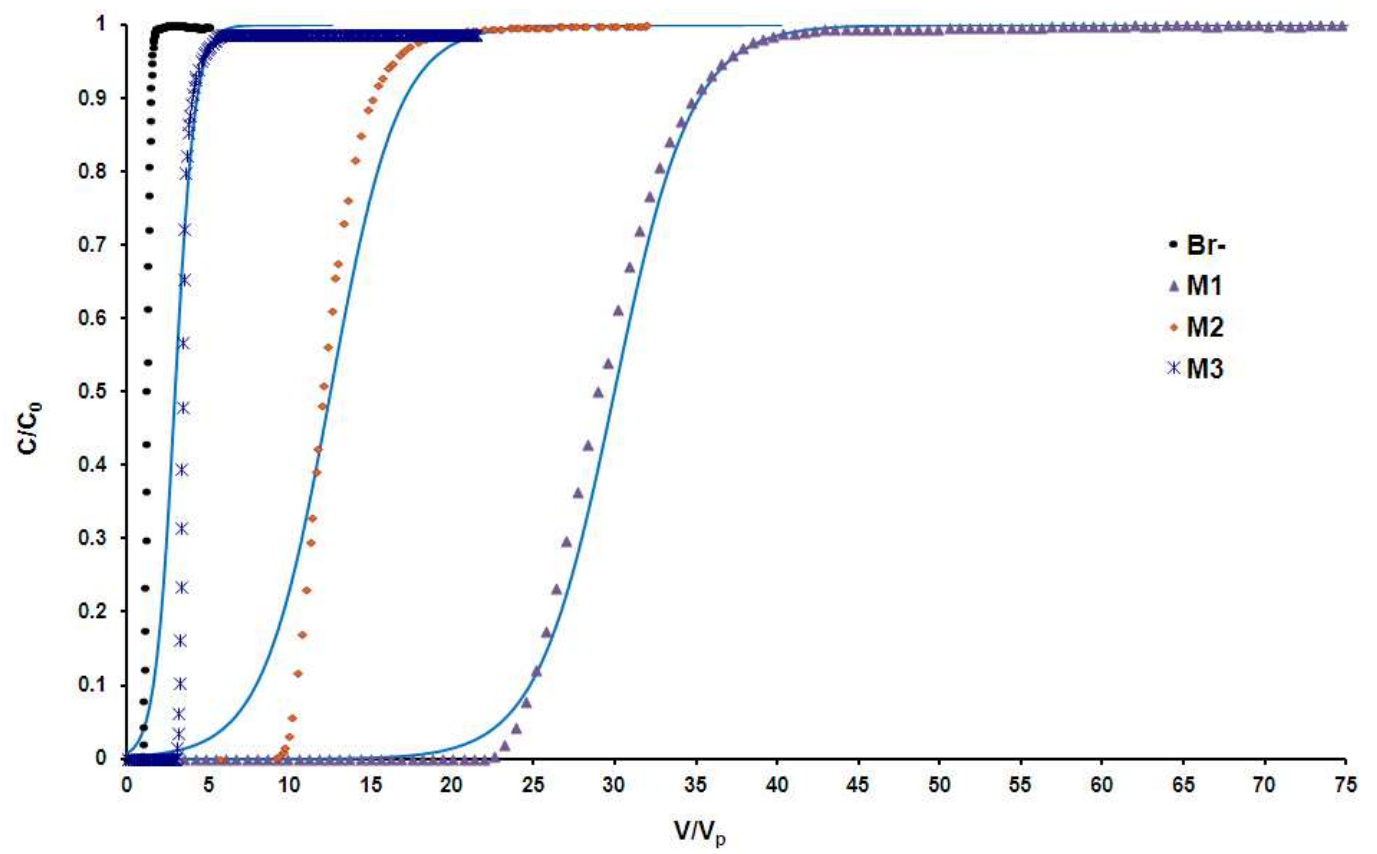


Fig. 5: (Yan model)

(a) $\mathrm{C}_{0}=50 \mu \mathrm{M}$

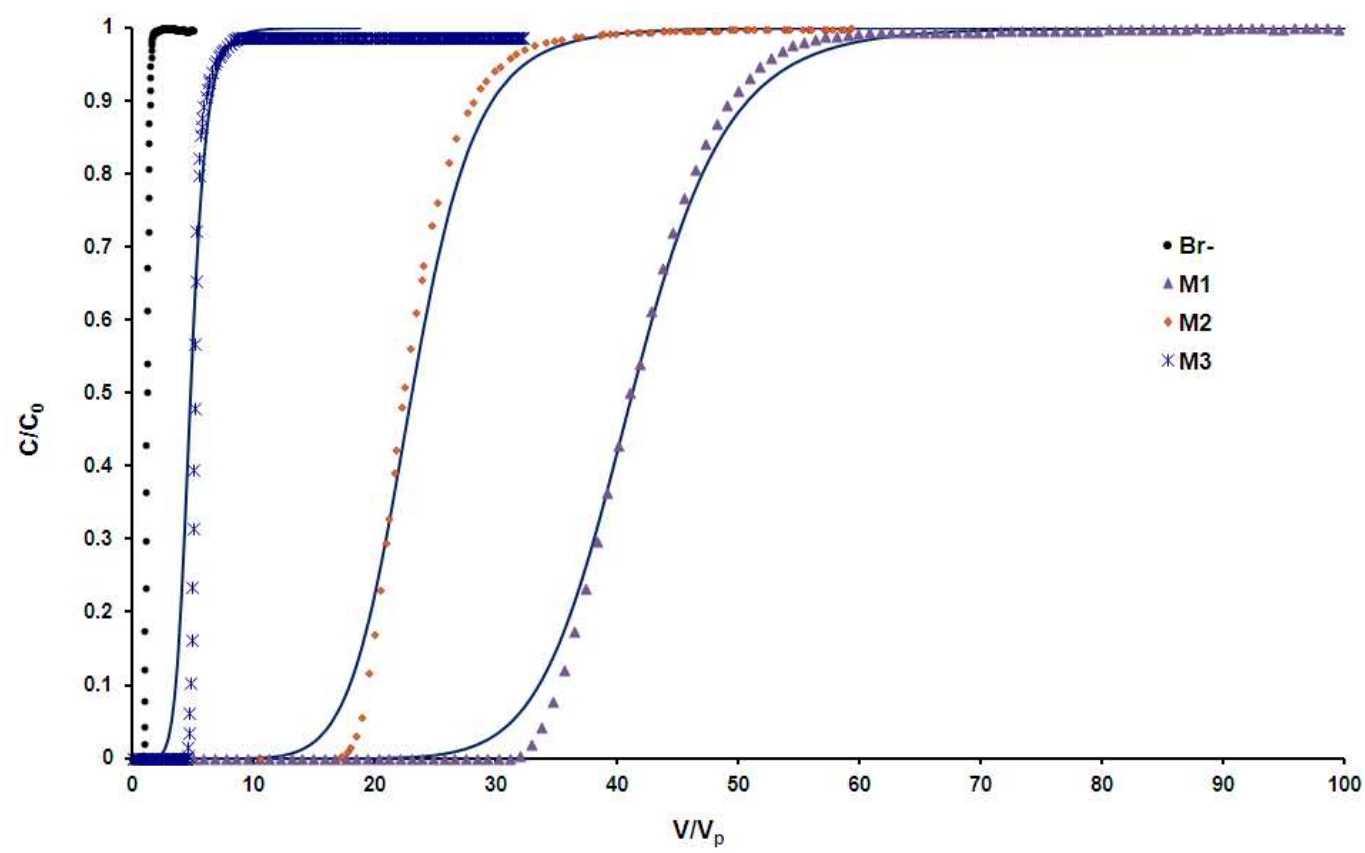

(b) $\mathrm{C}_{0}=200 \mu \mathrm{M}$

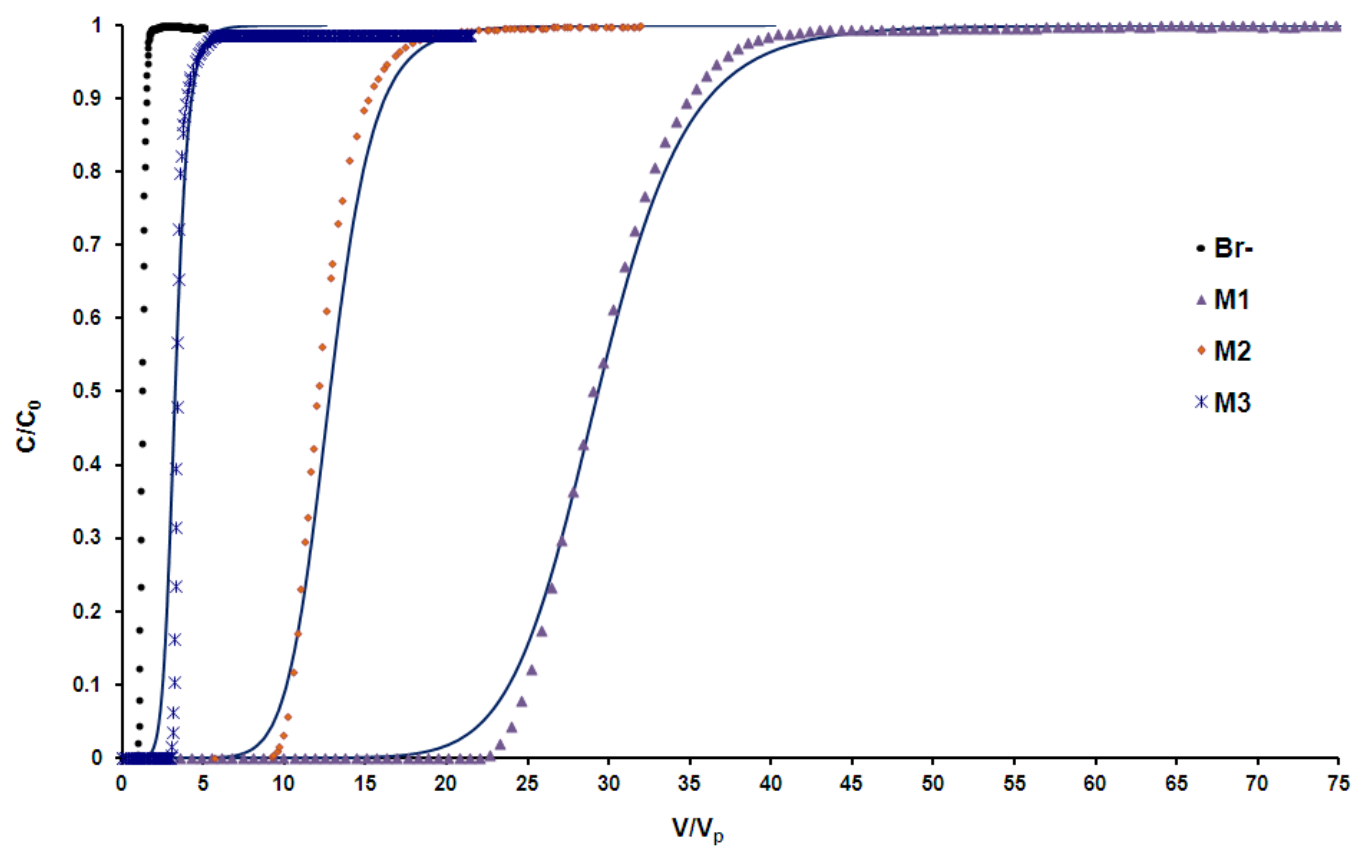

